\title{
O olhar de Peter Burke para a cultura material através das imagens
}

\section{La mirada de Peter Burke a la cultura material a través de imágenes}

\section{Peter Burke's look at material culture through images}

Anna Christina Madrid

Mestranda na Universidade Presbiteriana Mackenzie, São Paulo, Brasil.eahc.pos@mackenzie.br 


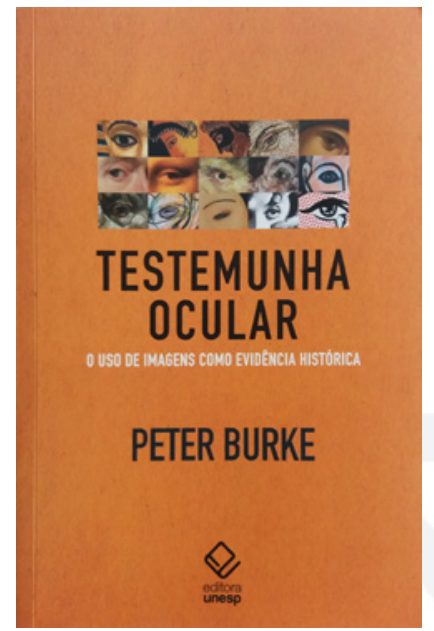

\section{O Olhar de Peter BuRke para A CUltura material}

\section{ATRAVÉS DAS IMAGENS}

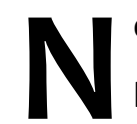

o livro "Testemunha ocular: o uso de imagens como evidência histórica", de Peter Burke, historiador e professor de História da Cultura na Universidade de Cambridge, o autor defende que: as imagens após serem submetidas às "críticas das fontes", pertinentes ao rigor científico, podem ser tão confiáveis quanto os textos escritos.

Burke, procura mostrar ao historiador a importância das imagens, como fontes históricas. O livro não busca ser um guia com fórmulas para servir de análise das imagens visuais como fontes, e sim informar, principalmente entre suas principais funções, as armadilhas que as imagens podem oferecer a quem as analisa; justamente por possuírem um rápido entendimento e compreensão, diferentemente da forma descritiva de um texto.

Com um prefácio escrito pelo próprio autor na edição brasileira, onde ressalta, já na introdução, os questionamentos de historiadores céticos quanto às 
ambiguidades que podem ocorrer no mau uso de imagens, ele defende que tais problemas, também, podem ocorrer com textos que são traduzidos de uma outra língua. Burke deixa claro o papel que o historiador deve ter, advertindo-o que ao utilizar as imagens faz-se necessário outros tipos de evidências, aos quais precisam desenvolver métodos para estudá-las, assim como o fizeram para com os textos (aqui ele faz uma breve comparação com o papel interrogatório que os advogados assumem em um julgamento).

Um ponto interessante que aparece no início do livro, é quando o autor afirma preferir o termo "indícios" ao invés de "fontes", quando nos explica:

Tradicionalmente, os historiadores têm se referido aos seus documentos como "fontes", como se eles estivessem enchendo baldes no riacho da Verdade, suas histórias tornando-se cada vez mais puras, à medida que se aproximam das origens. A metáfora é vívida, mas também ilusória no sentido de que implica a possibilidade de um relato do passado que não seja contaminado por intermediários. (BURKE, 2017, p.23).

Com uma didática de síntese e uma ampla visão diante do assunto, somos levados a transitar por um interessante roteiro ao longo da leitura, abordados em seus onze capítulos, começando pela função da fotografia e da pintura, onde o autor nos faz um alerta pelo o que elas podem e querem de fato nos mostrar. Enquanto no segundo capítulo, Burke trata da iconografia e da iconologia esclarecendo a semelhança e distinção entre ambas, mostrando que o historiador precisa delas ao mesmo tempo que deve ir além delas. No terceiro capítulo, é tratado o uso de imagens nas religiões, conforme citado por Burke: "em muitas religiões as imagens desempenham um papel crucial na criação da experiência do sagrado". Aspectos mais políticos é o tema que será abordado no quarto capítulo, onde a imagem é usada como arma de protesto devido ao poder que elas possuem.

A imagem retratada como um meio propagador e reconstrutor da cultura material do passado, é discutida no quinto capítulo, enquanto no sexto, 
intitulado "Visões de sociedade", Burke aborda a retratação de determinados aspectos sociais e seus elementos.

No sétimo capítulo, ele fala do perigo das ideias preconcebidas, que aparece nas imagens e, faz novamente um alerta, de que "o estereótipo pode não ser completamente falso, mas frequentemente exagera alguns traços da realidade e omite outros". No oitavo capítulo, ele fala das "Narrativas Visuais", partindo do princípio de que toda a imagem tem e conta uma história (seja em uma imagem ou em várias).

Entrando no nono capítulo, ele fala sobre o pintor e o cineasta, através da pintura histórica e do filme histórico como disseminadores da história, quando deixam de ser testemunhas de um fato e passam a ser "historiadores", alertando para o cuidado com as diversas armadilhas da imagem, ressaltando a importância de se empreender uma crítica e uma investigação das fontes utilizadas, pois devemos questionar se isso é uma recriação dos fatos, do ponto de vista do artista ou de um outro olhar, assim como, devemos procurar buscar as intenções do artista quando retratam suas obras. Assim, nos perguntando, se há uma outra intenção, ou intertextualidade na imagem, que cita outra imagem?

Já finalizando a leitura, nos capítulos dez e onze, onde são abordados os aspectos psicológicos e culturais das formas visuais, onde o autor discute se existe uma alternativa para a iconografia e a iconologia e, aponta três possibilidades (já mencionados em capítulos anteriores) que serão vistas pelos enfoques da psicanálise, do estruturalismo e da história social da arte.

Procurando criar uma simples análise deste autor, sobre a importância da imagem como documento histórico, com o olhar de outros pesquisadores, como Ulpiano Teixeira de Menezes, podemos compreender quando diz:

Por certo, nesse rumo, não poderei dispensar-me, inicialmente, de tocar em questões de base, conceituais ou teóricas, sobre algumas características genéricas dos objetos materiais, principalmente quando mobilizados como documentos. (1994, p.90). 
Considerando a importância destes olhares, exemplificados tão claramente neste livro, onde o autor nos conscientiza de que as imagens podem nos fornecer valiosos testemunhos que a escrita ou a oralidade não o podem, na maior parte das vezes por um distanciamento da época retratada.

Finalizando e sintetizando a importância deste livro, conforme nos mostra Peter Burke: "A proposta essencial que este livro tenta defender e ilustrar é a de que imagens, assim como textos e testemunhos orais, são uma forma importante de evidência histórica. Elas registram atos de testemunho ocular" (BURKE, 2017, p.25). Vale ressaltar que foi escrito tanto para encorajar o uso de tal evidência, quanto para advertir o usuário em potencial, a respeito de possíveis perigos e é exatamente isto que torna a leitura tão indispensável aos estudiosos e interessados na história.

Sobre o autor - Peter Burke é um historiador inglês nascido em 1937, atualmente professor emérito da Universidade de Cambridge. Durante sua carreira, lecionou em outras instituições de prestígio, como as Universidades de Princeton e Essex; foi professor visitante da Universidade de São Paulo entre 1994 e 1995. Especialista em História Moderna Europeia, é autor de, entre outros títulos, História e teoria social, $A$ arte da conversação, $A$ escrita da história: novas perspectivas e $O$ que é história do conhecimento? editados pela Editora Unesp.

\section{Bibliografia CitAda}

BURKE, Peter. Testemunha ocular: o uso de imagens como evidência histórica; traduzido por Vera Maria Xavier dos Santos; São Paulo: Editora Unesp, 2017.

MENEZES, Ulpiano T. Bezerra de. Memória e cultura material: documentos pessoais no espaço público. Revista Estudos Históricos, Rio de Janeiro, v. 11, n. 21, p. 89-104, jul. 1998. ISSN 2178-1494. Disponível em:<http://bibliotecadigital.fgv.br/ojs/index.php/reh/article/view/2067 /1206>. Acesso: 24 Nov. 2019. 